\title{
Effect of Mulching and Controlled Irrigation on On-Farm Crop Water Utilization and Quality of Litchi (Litchi chinensis Sonn.) cv. Dehradun
}

\author{
Ambika Bhandari, Arti Sharma*, V.K. Wali and Darpreet Kour
}

Division of Fruit science, Faculty of Agriculture, Sher-e-Kashmir University of Agricultural Sciences and Technology of Jammu-180009, India

*Corresponding author

\section{A B S T R A C T}

\begin{tabular}{|l|}
\hline Ke y w o r d s \\
Cracking, Irrigation, \\
Litchi, Mulching, \\
Yield \\
\hline Article Info \\
\hline $\begin{array}{l}\text { Accepted: } \\
\text { 04 January } 2018 \\
\text { Available Online: } \\
\text { 10 February } 2018\end{array}$ \\
\hline
\end{tabular}

A study was conducted at the Research Farm, Division of Fruit Science, FOA Udheywalla, Sher-e-Kashmir University of Agricultural Sciences and Technology of Jammu, J\&K India on twenty year old plants of Litchi cultivar Dehradun. Trees were subjected to mulching with different types of materials (black polythene and paddy straw) and supplied with irrigations @ 200 liters / tree at 3,6 and 9 days intervals. Results revealed that the trees supplied with irrigation at 6 days intervals and mulched with black polythene i.e., $\mathrm{T}_{8}$ showed Black polythene mulch and irrigation at 6 days interval was superior in terms of chemical characteristics of fruits viz., total soluble solids $\left(19.4^{\circ} \mathrm{Brix}\right)$, TSS: acid ratio (34.49), ascorbic acid $(45.35 \mathrm{mg} / 100 \mathrm{~g})$, anthocyanin content $(52.13 \mathrm{mg} / 100 \mathrm{~g})$ and pectin content $(0.72 \%)$. Titratable acidity $(0.69 \%)$ was recorded highest in plant mulched with black polythene and irrigation at 9 days interval.

\section{Introduction}

The litchi (Litchi chinensis Sonn.) is the most important sub-tropical evergreen fruit tree and belongs to the family Sapindaceae. It is highly prized fruit both in its fresh and preserved forms. India is the second largest producer of litchi in the world after china. In India Litchi is grown under an area of 85.00 thousand hectare with a total production of 594.00 thousand metric tonnes (NHB, 2014). It is grown in the states of Bihar, Tripura, West Bengal, Uttar Pradesh, Punjab and Haryana. Litchi makes significant contribution to the lives and economic health of millions of people in the South East Asia (Mitra and Pathak, 2010). The litchi fruit is a good source of food, nutrition and has good medicinal value. The fruit of the litchi comes to the market in May or early June when very few other fruits are available, thus they fetch remunerative price in the market and thus rules the domestic market as "Queen of fruits" during the season. The litchi fruit is also a rich source of vitamin C (Wall, 2006) and phenolic compounds that have antioxidant activities (Hu et al., 2010). Sucrose; fructose and glucose are found to be the major sugars in 
litchi (Paull et al., 1984; Jiang et al., 2006; Hu et al., 2010). The fruits are high in sugars and also contain several minerals (Robert et al., 2000).

The cultivation of litchi fruit and its fruit quality is highly sensitive to water deficit (Spreer et al., 2007) which aggravates the fruit cracking and shortens the post harvest life. Further complexities in optimizing irrigation emerge due to different cultivars, plant sizes, and fruit developmental stages (Li et al., 2001; Khurshid et al., 2004). Several attempts have been made to standardize nutrient and water requirement of litchi tree in India (Hassan and Chattopadhyay, 1997). Water relations are very important to the function of the litchi tree, as water is the greatest component of the tree by mass and almost all critical processes can be limited by inappropriate water status. The Irrigation intervals affect physicochemical quality attributes and skin cracking in litchi fruit. Dehradun an early variety of litchi, which matures in $2^{\text {nd }}$ week of June, despite of its all good qualities it tends to undergo massive fruit cracking which drastically reduces the yield and hence responsible for poor litchi productivity.

General practice adapted by Litchi grower's to avoid fruit cracking is by over irrigation. Due to climate change and dwindling water resources Indian agriculture is suffering from a great stress of water scarcity thus the practice of over and excessive irrigation need to be stopped and irrigation requirements of individual fruit crops need to be optimized specially for the water sensitive crops like Litchi in order to get good quality fruit from less irrigation water. Thus the present investigation was undertaken to study the effect of controlled irrigation at fixed intervals combined with an established practice of water conservation i.e. mulching to see if quality litchi fruits can be produced with less irrigation water.

\section{Materials and Methods}

An experiment was conducted on twenty year old litchi orchard of cv. Dehradun. Trees of uniform vigour and size, maintained under uniform cultural practices growing at Research Farm, Division of Fruit Science, FoA Udheywalla, Sher-e-Kashmir University of Agricultural Sciences and Technology of Jammu, Jammu \& Kashmir, India, 180001 during 2014 (32.73 ${ }^{0}$ North latitude and 74.87 ${ }^{0}$ East longitude) were selected for the study. The experiment was statistically laid out as per Randomized Block Design. The treatment imposed were, $\mathrm{T}_{1}$ - Irrigation at 3 days interval, $\mathrm{T}_{2}$ - Irrigation at 6 days interval, $\mathrm{T}_{3}$ - Irrigation at 9 days interval, $\mathrm{T}_{4}$ - Paddy straw + irrigation at 3 days interval, $\mathrm{T}_{5}$ - Paddy straw + irrigation at 6 days interval, $\mathrm{T}_{6}$ - Paddy straw + irrigation at 9 days interval, $\mathrm{T}_{7}-$ Black Polythene + irrigation at 3 days interval, $\mathrm{T}_{8}-$ Black Polythene + irrigation at 6 days interval, $\mathrm{T}_{9}$ Black Polythene + irrigation at 9 days interval.

Selected trees were subjected to mulching with two types of materials (black polythene and paddy straw) and controlled irrigations @ 200 liters/ tree at 3, 6, 9 intervals. Regulated irrigations were applied from the fruit set till harvesting. Chemical characteristics of fruits viz., total soluble solids, TSS: acid ratio, ascorbic acid, anthocyanin content, pectin content and titratable acidity were recorded according to standard procedure as given in A.O. A.C., (1995). The total soluble solids (TSS) of the fruit juice were recorded with the help of Erma hand refractometer $\left(0-32^{0} \mathrm{~B}\right)$ according to standard procedure as given in A.O. A.C., (1994) in terms of degree Brix $\left({ }^{0} B\right)$ at room temperature.

\section{Results and Discussion}

A significant response of application of mulch along with irrigation at 6 days interval on fruit chemical characteristics was observed over 
other treatments. Results revealed that trees supplied with irrigation at 6 days intervals and mulched with black polythene superior in terms of chemical characteristics of fruits viz., total soluble solids $\left(19.4^{\circ} \mathrm{Brix}\right)$, TSS: acid ratio (34.49), ascorbic acid (45.35mg/100g), anthocyanin content $(52.13 \mathrm{mg} / 100 \mathrm{~g})$ and pectin content $(0.72 \%)$ whereas, minimum total soluble solids $\left(16.54^{\circ} \mathrm{Brix}\right)$, TSS: acid ratio (23.97), ascorbic acid $(38.50 \mathrm{mg} / 100 \mathrm{~g})$, anthocyanin content $(46.30 \mathrm{mg} / 100 \mathrm{~g})$ and pectin content $(0.42 \%)$ was recorded in plant mulched with black polythene and irrigation at 9 days interval.

Titratable acidity $(0.69 \%)$ was recorded highest in plant mulched with black polythene and irrigation at 9 days interval.

These results are in conformity with Bal and Singh (2011) who reported that maximum TSS was recorded under black polythene mulch because of higher soil temperature as there is more accumulation of reserve substance in fruit and hence more TSS. As far as effect of irrigation is concerned increase in
TSS with the increase in irrigation interval has been reported by Al- Yahyai and Al- Kharusi (2012), who have reported that TSS was highest in weekly irrigated tress and lowest in fruits of daily irrigated trees. Mitchell et al., (1991) reported that increase in soluble solids of the tomato fruit grown under soil water deficits are related primarily to decreases in fruit water content and to slight increase in soluble sugar accumulation.

Maximum TSS: acid ratio (34.49) was recorded in fruits under $\mathrm{T}_{8}$ (Black polythene + irrigation at 6 days interval) while, minimum TSS: acid ratio (23.97) was recorded in $\mathrm{T}_{9}$ (Black polythene + irrigation at 9 days interval). These changes in quality attributes may be due to the higher soil temperature which may be the principle cause as suggested by Tang et al., (1984). As far as effect of irrigation is concerned increase in TSS: acid ratio with the increase in irrigation interval has been reported by Sotiropoulos et al., (2010) who stated that regulated deficit irrigation increased soluble solids/acid ratio in clingstone peaches as compared to control.

Table.1 Effect of mulching and controlled irrigation on chemical characteristics of Litchi (Litchi chinensis Sonn.) cv. Dehradun

\begin{tabular}{l} 
Treatments \\
\hline $\mathrm{T}_{1}$ (Irrigation at 3 days interval [control]) \\
$\mathrm{T}_{2}$ (Irrigation at 6 days interval) \\
\hline $\mathrm{T}_{3}$ (Irrigation at 9 days interval) \\
\hline $\mathrm{T}_{4}$ (Paddy Straw + irrigation at 3 days interval) \\
\hline $\mathrm{T}_{5}$ (Paddy Straw + irrigation at 6days interval) \\
\hline $\mathrm{T}_{6}$ (Paddy Straw + irrigation at 9days interval \\
\hline $\mathrm{T}_{7}$ (Black Polythene + irrigation at 3 days \\
interval)) \\
\hline $\mathrm{T}_{8}$ (Black Polythene + irrigation at 6days \\
interval) \\
\hline T 9 (Black Polythene + irrigation at 9days \\
interval) \\
\hline C.D at $5 \%$
\end{tabular}

\begin{tabular}{|c|c|c|}
\hline $\begin{array}{c}\text { Total soluble } \\
\mathbf{0}\end{array}$ & $\begin{array}{c}\text { Titratable } \\
\text { Acidity }(\boldsymbol{\%})\end{array}$ & $\begin{array}{c}\text { TSS: Acid } \\
\text { ratio }\end{array}$ \\
\hline 17.80 & 0.61 & 29.15 \\
\hline 17.59 & 0.62 & 28.44 \\
\hline 16.62 & 0.67 & 24.87 \\
\hline 18.85 & 0.60 & 31.42 \\
\hline 18.92 & 0.59 & 32.19 \\
\hline 17.46 & 0.65 & 26.95 \\
\hline 19.21 & 0.58 & 33.26 \\
\hline 19.40 & 0.56 & 34.49 \\
\hline 16.54 & 0.69 & 23.97 \\
\hline 1.82 & 0.06 & 6.49 \\
\hline
\end{tabular}


Table.2 Effect of mulching and irrigation intervals on chemical characteristics of Litchi (Litchi chinensis Sonn.) cv. Dehradun

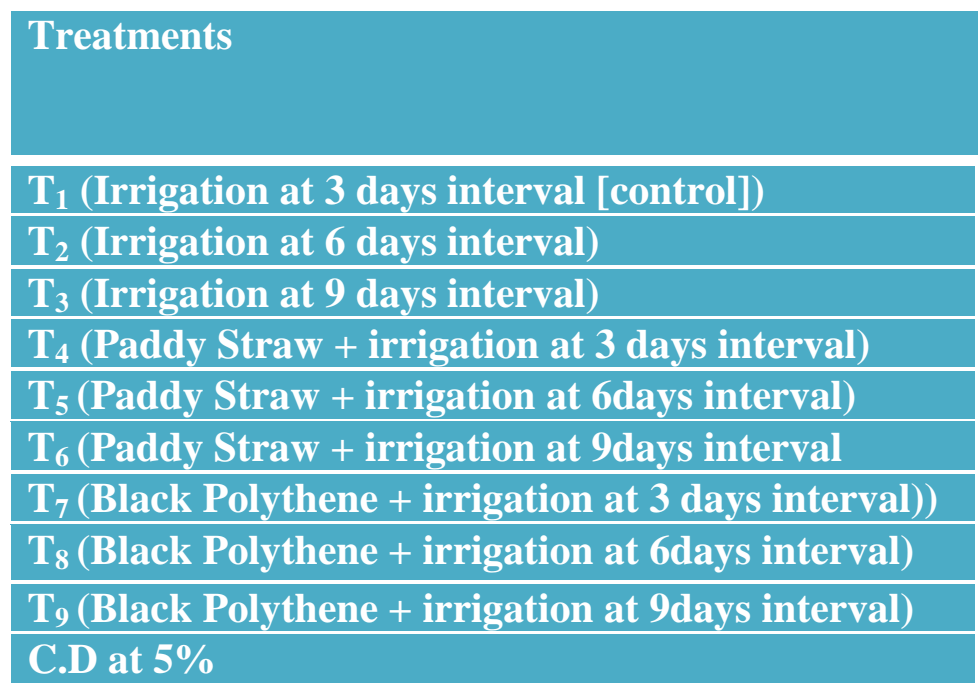

Appreciable improvement in fruit quality in terms of ascorbic acid values obtained by various mulching treatments might be associated with increase in soil moisture conservation which ultimately caused mobilization of soluble carbohydrates in the fruit. The result is in conformity with (Bal and Singh, 2011) who reported that maximum ascorbic acid is estimated in fruit mulched with black polythene in ber. As far as results regarding effect of irrigation intervals are concerned, increase in irrigation interval from 3 to 6 days resulted into increased in ascorbic acid content but when irrigation interval was further increased to 9 days, a significant decrease in ascorbic acid content was recorded.

Maximum anthocyanin content $(52.13 \mathrm{mg}$ $/ 100 \mathrm{~g}$ ) was recorded under $\mathrm{T}_{8}$ (Black polythene + irrigation at 6 days interval. The least reading $(46.30 \mathrm{mg} / 100 \mathrm{~g})$ was recorded under $\mathrm{T}_{9}$ (Black polythene + irrigation at 9 days interval). The presence of anthocyanin in the litchi fruits exhibit excellent antioxidant activity they significantly inhibit the peroxidation of linoleic acid and act as strong electron donating agents in $\mathrm{Fe}^{3+}$ to $\mathrm{Fe}^{2+}$ assay

\begin{tabular}{|c|c|c|}
\hline $\begin{array}{c}\text { Ascorbic } \\
\text { acid } \\
(\mathbf{m g} / \mathbf{1 0 0 g})\end{array}$ & $\begin{array}{c}\text { Anthocyanin } \\
\text { content (mg/100g) }\end{array}$ & $\begin{array}{c}\text { Pectin } \\
\text { content } \\
(\mathbf{\%})\end{array}$ \\
\hline 40.46 & 50.91 & 0.61 \\
\hline 39.58 & 50.16 & 0.56 \\
\hline 38.32 & 46.88 & 0.46 \\
\hline 41.52 & 51.09 & 0.63 \\
\hline 41.73 & 51.21 & 0.64 \\
\hline 38.82 & 48.49 & 0.52 \\
\hline 42.24 & 51.50 & 0.68 \\
\hline 45.35 & 52.13 & 0.72 \\
\hline 38.50 & 46.30 & 0.42 \\
\hline 0.59 & 0.79 & 0.03 \\
\hline
\end{tabular}

and hydrogen donating agents. The anthocyanin is effective in scavenging superoxide anion radical and inhibitor deoxiribose degradation induce by hydroxyl radical mainly via chelating iron ion rather than scavenging hydroxyl radical directly. The results are in conformity with the (Baba et al., 2010) who reported black polythene mulch produced fruit with high anthocyanin content in strawberry. This may be due to better soil hydrothermal regime, better moisture conservation and suppression of weeds in the plants.

As effect of irrigation is concerned, with the increase in irrigation intervals to 3 and 6 days, a significant increase in anthocyanin content was recorded. Thus irrigation at 6 days interval created mild water stress and use of black polythene mulch along with 6 days irrigation interval produce a synergistic effect on anthocyanin, thus resulted in maximum anthocyanin in this treatment.

Maximum pectin content $(0.72 \%)$ of litchi fruit was obtained with the black polythene mulch and irrigation at 6 days interval (Table 1 and 2). 
As far as results regarding effect of irrigation intervals are concerned, increase in irrigation interval from 3 to 6 days results into increased pectin content but when irrigation interval was further increased to 9 days a significant decrease in pectin content was recorded. These results are in conformity with the results of (Gribaa et al., 2012) in date palm who stated that possible reason for increase in pectin content during higher irrigation intervals might be due to the low levels of hydrophobic groups (methylester and Oacetyl) and the less intensive degradation of the hydrophilic galactan, arabinan and arabinogalactan in the cell wall may be implicated in maintaining the hydration status of the cells under water deficit.

It was concluded that in order to get positive fruiting results and better quality fruits in a litchi orchard water management conditions must improved by applying irrigations at 6 days interval (near-optimum moisture consumption conditions) and mulching trees with black polythene. This practice will result into increased on-farm crop water utilization and better quality fruits with less irrigation thereby conserving water which is getting scarce day by day.

\section{References}

A.O.A.C. 1994. Official Methods of Analysis. Association of Analytical chemist 15th Ed, Washington, D.C.

A.O.A.C. 1995. Official Methods of Analysis. Association of Analytical chemist 15th Ed, Washington, D.C.

Al-Yahyai R and Al- Kharusi L. 2012. Suboptimal irrigation affects chemical quality attributes of dates during fruit development. African Journal of Agricultural Research, 7(10): 14981503.

Baba J, Kher R, Bakshi, P and Wali, V K.
2010. Effect of planting time and mulching material on quality of strawberry. Journal of Research, SKUAST -J, 9(1):54-62.

Bal J S and Singh, S. 2011. Effect of mulching material and herbicides on tree growth, yield and fruit quality of ber. Indian Journal of Horticulture, 68 (2): 189-192.

Gribaa A, Dardelle F, Lehner A, Rihouey C, Burel C, Ferchichi A, Driouich A. and Mollet J C. 2012. Effect of water deficit on the cell wall of the date palm (Phoenix dactylifera) 'Deglet nour', Arecales fruit during development. Plant Cell and Environment, 36(5): 1056-1070.

Hassan M.A. and Chattopadhyay P K.1997. Leaf nutrient status and their correlative relationships with yield in Litchi $\mathrm{Cv}$. Bombai under the influence of $\mathrm{N}, \mathrm{P}, \mathrm{K}$ nutrition. Indian Agriculturist, 41(1):6169.

Hu Z Q, Huang X M, Chen H B and Wang H C. 2010. Antioxidant capacity and phenolic compounds in litchi (Litchi chinensis sonn.) pericarp. Acta Horticulture, 863: 567-574.

Jiang Y M, Wang Y, Song L, Liu H, Lichter A, Kerdchoechuen O, Joyce D C and Shi J. 2006. Postharvest characteristics and handling of litchi fruit - An overview. Australian Journal of Experimental Agriculture, 46: 15411556.

Khurshid S, Ahmad I. and Anjum M A. 2004. Genetic diversity in different morphological characteristics of litchi (Litchi chinensis Sonn.). International Journal of Agricultural Biology, 6: 1062-1065.

Li J G, Huang H B, Gao F F, Huang X M, Wang H C 2001. An overview of litchi fruit cracking. Acta Horticulture, 558: 205-208.

Mishra J N, Paul J C and Pradhan P C. 2008. 
Response of cashew to drip irrigation and mulching in coastal Orissa. Journal of Soil and Water Conservation, 7(3): 36-40.

Mitchell J P, C. Shenan S Grattan and D M. 1991. Tomato fruit yields and quality under water deficient and salinity. Journal of American Society of Horticultural Science, 116: 817-821.

Mitra S K, and Pathak P K. 2010. Litchi production in the Asia-Pacific region. Acta Horticulture 863:29-36.

NHB. 2014. Indian Horticulture Database, National Horticulture Board, Department of Agriculture and Cooperation. Government of India. Gurgaon.

Paull R E, Chen J N, Deputy, Huang J H, Cheng $G$ and Go F. 1984. Litchi growth and compositional changes during fruit development. Journal of American Society of Horticulture Science. 109: 817-821.

Robert C E, Arnold C, Jim P and Bryan W. 2000. Mineral nutrition during establishment of Golden Delicious cv. 'Smoothee' apples on dwarfing rootstocks and interstems. Journal of Plant Nutrition, 23: 1179-1192.

Sotiropoulus T, Kalfountzos D, Aleksiou I, Kotsopoulos S and Koutinas, N. 2010. Response of a clingstone peach cultivar to regulated deficit irrigation. Scientia Agricola (Piracicaba, Braz.), 67(2): 164-169

Spreer W, Hegele M, Czaczyk Z, Romheld V, Bangerth F, M. 2007. Water consumption of greenhouse lychee trees under partial root zone drying. Agri Eng Int 9: 1-10.

Tang L, Yang X and Han X. 1984. The effect of mulching with silver reflex film in apple orchard. Scientia Agriculture Sinica, 5: 259-60.

Wall M M. 2006. Ascorbic acid and mineral composition of longan (Dimocarpus longan), Lychee (Litchi chinensis) and rambutan (Nephelium lappaceum) cultivars grown in Hawaii. Journal of Food Composition, 19: 655-663.

\section{How to cite this article:}

Ambika Bhandari, Arti Sharma, V.K. Wali and Darpreet Kour. 2018. Effect of Mulching and Controlled Irrigation on On-Farm Crop Water Utilization and Quality of Litchi (Litchi chinensis Sonn.) cv. Dehradun. Int.J.Curr.Microbiol.App.Sci. 7(02): 249-254. doi: https://doi.org/10.20546/ijcmas.2018.702.032 